\title{
Aortic Valve Myxoma Presenting with a Stroke A case report and review of the literature
}

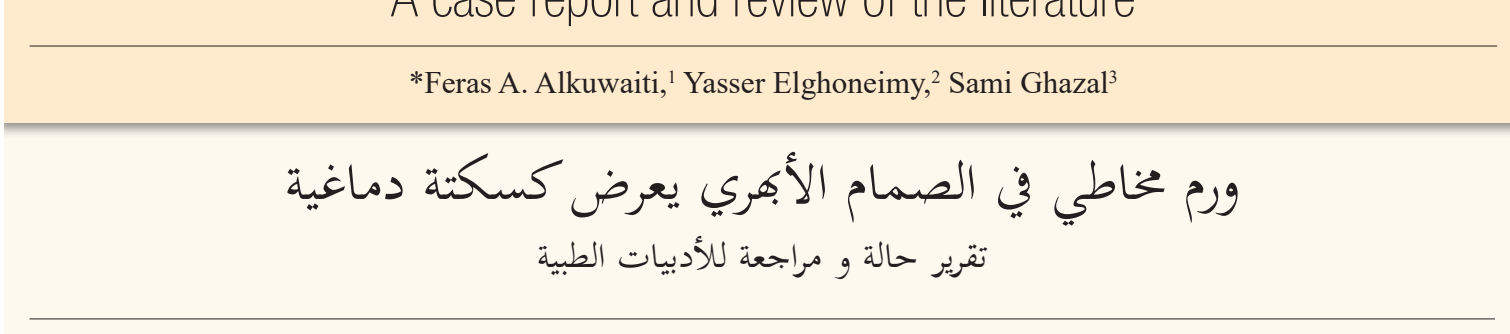

$$
\text { فراس أحمد الكويتي، ياسر الغنيمي، سامي غزال }
$$

ABSTRACT: Myxomas originating from the aortic valve are rare. We report a 40-year-old male patient who presented to the King Fahd Hospital of the University, Khobar, Saudi Arabia, in 2017 with a stroke. Transoesophageal echocardiography indicated a mobile mass measuring $6 \times 2 \mathrm{~mm}$ attached to the right coronary cusp of the aortic valve and a mobile interatrial septum with a small patent foramen ovale (PFO). The patient underwent surgical excision of the mass and direct closure of the PFO. Histopathology confirmed the mass to be a myxoma. Despite their rarity, the recognition and treatment of valvular myxomas is very important; moreover, clinicians should be aware that affected patients may present with an embolic stroke.

Keywords: Aortic Valve; Myxoma; Patent Foramen Ovale; Stroke; Transesophageal Echocardiography; Case Report; Saudi Arabia.

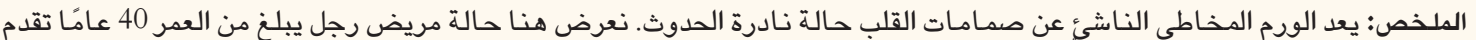

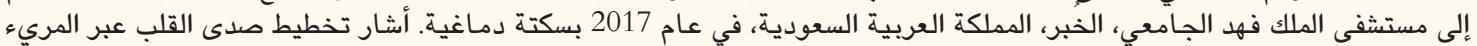

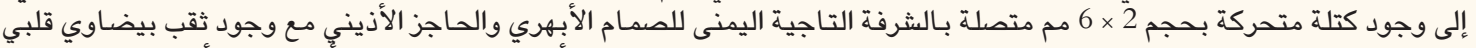

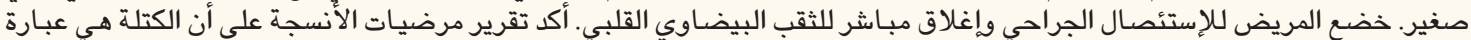

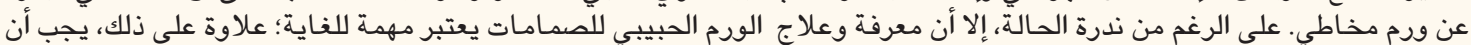

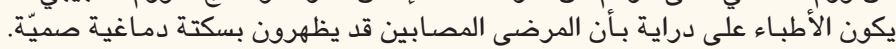

$$
\begin{aligned}
& \text { الكلمات المفتاحية: الصمام الأبهري؛ ورم مخاطي؛ الثقب البيضاوي القلبي؛ السكتة الدماغية؛ تخطيط صدى القلب عبر المري؛؛ تقرير حالة؛ المملكة } \\
& \text { العربية السعودية. }
\end{aligned}
$$

$M$ XOMAS ORIGINATING FROM THE CARDIAC valves are uncommon. ${ }^{1,2}$ These benign tumours typically occur between the fourth and seventh decades of life and usually affect women more commonly than men. ${ }^{1}$ The condition is mostly sporadic in nature, but can also be familial. ${ }^{2}$ Myxomas are true neoplasms in that they are derived from primitive multipotent mesenchymal cells which may exist as embryonic remnants in the heart wall. ${ }^{3}$

Rarely, myxomas may arise from both the ventricular aspect and the margin of the aortic valve cusps; moreover, one or both leaflets may also be affected. ${ }^{4}$ Although transoesophageal echocardiography (TEE) aids in the assessment of such masses, histopathology is considered the gold-standard method to confirm a diagnosis. ${ }^{4,5}$ This report describes an atypical case of aortic valve myxoma and patent foramen ovale (PFO) presenting with a cerebral stroke. Such cases serve to increase awareness of the varying presentation of aortic valve myxomas and highlight appropriate investigations and management of this condition.

\section{Case Report}

A 40-year-old male patient presented to the King Fahd Hospital of the University (KFHU), Khobar, Saudi Arabia, in 2017 with sudden-onset dysphasia, left ataxia, nausea and vomiting over the preceding two hours. The patient reported having had a previous stroke at the age of 11 years; however, he was unable to provide any information about the event. At presentation, the patient was alert, oriented and had stable vital signs. All laboratory investigation findings were within normal limits and electrocardiography showed normal sinus rhythm. As a result, the case was transferred to the stroke team. Urgent computed tomography (CT) of the head showed evidence of the prior ischaemic stroke event in the right occipital lobe and right cerebellum. An intravenous thrombolytic was administered in accordance with hospital guidelines. Subsequently, the patient was admitted to the inpatient department and received $150 \mathrm{mg}$ of aspirin and $75 \mathrm{mg}$ of clopidogrel. Symptoms improved over the course of the following three days. However, 

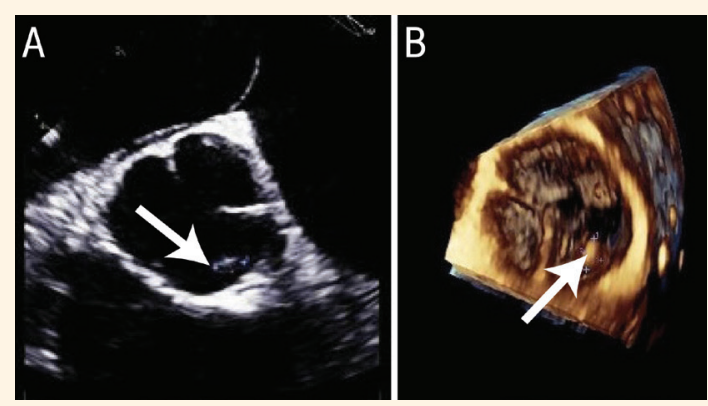

Figure 1: Transoesophageal echocardiography of a 40year-old male stroke patient in (A) bi-plane short-axis view showing a small mass in the right coronary cusp of the aortic valve measuring $3 \times 5 \mathrm{~mm}$ and (B) threedimensional enfaced view showing the mass measuring $6 \times 2 \mathrm{~mm}$.

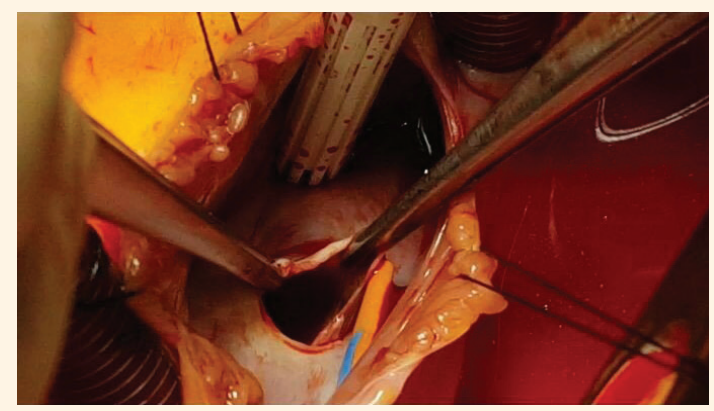

Figure 2: Intraoperative photograph of the heart of a 40-year-old male stroke patient showing an opening between the right and left atria measuring $10 \times 10 \mathrm{~mm}$.

further investigations were undertaken to determine the source of the stroke.

Brain magnetic resonance imaging (MRI) revealed that the patient had suffered an acute ischaemic stroke, with a multifocal area of diffusion restriction within the right cerebral and superior cerebellar peduncles and both cerebellar hemispheres, as well as hyperintensities on T2-weighted fluid-attenuated inversion recovery MRI sequences. However, transthoracic echocardiography (TTE) did not show any clear source of emboli. Accordingly, TEE was performed and revealed a small mobile mass measuring $6 \times 2 \mathrm{~mm}$ attached to the right coronary cusp (RCC) of the aortic valve and a mobile interatrial septum with a small PFO visible with agitated saline contrast [Figure 1]. No significant arrhythmia was noted on a Holter monitor. A papillary fibroelastoma (PFE) was suspected.

After two weeks of stroke management, the decision was made excise the mass along with closure of the PFO to prevent any future embolic events. The surgical procedure was performed while the patient underwent cardiopulmonary bypass. During the surgery, the PFO was visible as an opening between the right and left atria [Figure 2]. The mass was successfully excised from the RCC and the PFO was closed. The postoperative period was uneventful and the patient was discharged five days later. A histopathological examination of the excised mass showed a paucicellular lesion composed of stellate and oval cells with a moderate amount of eosinophilic cytoplasm, fine chromatin and indistinct cell borders [Figure 3]. These features were consistent with a diagnosis of myxoma.

\section{Discussion}

To the best of the authors' knowledge, only 11 cases of aortic valve myxoma have been previously reported in the literature [Table 1].4-14 Interestingly, nine of these previously reported patients were male, as in the current case; this is contrary to the usual female preponderance of myxoma cases. ${ }^{1,-9,11,13,14}$ Overall, six aortic valve myxoma patients were symptomatic, with symptoms largely attributable to distal embolisation and ischaemia, including three cases with stroke, two with myocardial infarctions and one with limb ischaemia. ${ }^{4,6,8,11-13}$ Clinicians should therefore be aware of stroke as a potential presentation of aortic valve myxoma.

The pathogenesis of ischaemic events in aortic valve myxoma could be due to either embolic debris derived from the tumour itself or from a thrombus around the tumour. ${ }^{12}$ In the current case, the patient was also diagnosed with PFO, a potential cause of embolic stroke in which a paradoxical embolism may pass through a PFO via right-to-left shunting (RLS). ${ }^{15}$ However, in the current case, the observed PFO was very small in size and therefore would not be able to cause the RLS of an embolus.
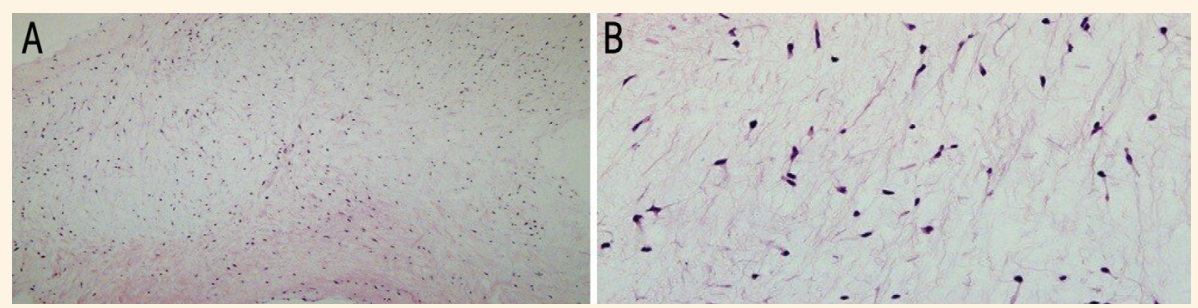

Figure 3: Haematoxylin and eosin stains at (A) x40 magnification showing a hypocellular lesion in a myxoid matrix and (B) at X200 magnification showing stellate and oval cells with eosinophilic cytoplasm and indistinct cell borders. 
Table 1: Literature review of reported aortic valve myxoma* cases $^{4-14}$

\begin{tabular}{|c|c|c|c|c|c|c|c|c|}
\hline $\begin{array}{l}\text { Author and year } \\
\text { of case" }\end{array}$ & $\begin{array}{l}\text { Age/ } \\
\text { gender }\end{array}$ & Presentation & History & Imaging & Site & $\begin{array}{l}\text { Size in } \\
\mathrm{cm}\end{array}$ & Complication & Surgery \\
\hline $\begin{array}{l}\text { Kennedy et al. }{ }^{8} \\
\text { (1995) }\end{array}$ & $23 / \mathrm{M}$ & Leg pain & None & TTE & $\begin{array}{l}\text { RCC } \\
\text { and } \\
\text { LCC }\end{array}$ & 1.5 & Limb ischaemia & AVR \\
\hline $\begin{array}{l}\text { Watarida et al. } \\
\text { (1997) }\end{array}$ & $58 / \mathrm{M}$ & Asymptomatic & None & TTE & RCC & $1.1 \times 1$ & None & AVR \\
\hline $\begin{array}{l}\text { Ramsheyi et al. } \\
\text { (1998) }\end{array}$ & $34 / \mathrm{M}$ & $\begin{array}{c}\text { Facial } \\
\text { haemiparesis }\end{array}$ & None & $\begin{array}{c}\text { TTE } \\
\text { and TEE }\end{array}$ & RCC & 1 & Stroke & AVR \\
\hline $\begin{array}{l}\text { Okamoto et al. }{ }^{10} \\
(2006)\end{array}$ & $61 / F$ & Endocarditis & $\begin{array}{c}\text { HTN } \\
\text { and DM }\end{array}$ & TTE & LCC & $1 \times 1$ & None & Resection \\
\hline Dyk et al. ${ }^{11}$ (2009) & $15 / M$ & Chest pain & None & $\begin{array}{c}\text { TTE } \\
\text { and TEE }\end{array}$ & $\mathrm{NCC}$ & $4 \times 1$ & MI & Resection \\
\hline $\begin{array}{l}\text { Koyalakonda et al. }{ }^{12} \\
\text { (2011) }\end{array}$ & $60 / F$ & Paroxysmal AF & $\begin{array}{l}\text { AF and } \\
\text { HTN }\end{array}$ & $\begin{array}{c}\text { TTE } \\
\text { and TEE }\end{array}$ & RCC & $1 \times 1$ & Stroke & Resection \\
\hline $\begin{array}{l}\text { Fernández et al. }{ }^{13} \\
\text { (2012) }\end{array}$ & $28 / \mathrm{M}$ & Haemiparesis & Epilepsy & TTE & $\begin{array}{l}\text { RCC } \\
\text { and } \\
\text { LCC }\end{array}$ & $1.5 \times 0.7$ & Stroke & AVR \\
\hline Kim et al..$^{7}$ (2012) & $72 / \mathrm{M}$ & $\begin{array}{l}\text { Shortness of } \\
\text { breath }\end{array}$ & HTN & TTE & NCC & $1.5 \times 0.8$ & None & AVR \\
\hline Javed et al. ${ }^{4}(2014)$ & $81 / \mathrm{M}$ & Leg pain & $\begin{array}{c}\text { HTN, } \\
\text { CKD } \\
\text { and PAD }\end{array}$ & $\begin{array}{c}\text { CT, } \\
\text { angiography } \\
\text { and TEE }\end{array}$ & LCC & $1.8 \times 1.2$ & Acute MI & $\begin{array}{l}\text { CABG } \\
\text { and } \\
\text { resection }\end{array}$ \\
\hline Prifti et al. ${ }^{5}$ (2015) & $13 / \mathrm{M}$ & $\begin{array}{l}\text { Dyspnoea and } \\
\text { angina }\end{array}$ & None & $\begin{array}{c}\text { TTE } \\
\text { and TEE }\end{array}$ & $\begin{array}{l}\text { RCC } \\
\text { and } \\
\text { LCC }\end{array}$ & $0.6 \times 0.2$ & None & AVR \\
\hline Ji et al. ${ }^{14}(2017)$ & $17 / \mathrm{M}$ & Heart murmur & None & TTE & NCC & 2 & None & AVR \\
\hline Present case (2018) & $40 / \mathrm{M}$ & $\begin{array}{l}\text { Dysphasia, } \\
\text { ataxia and } \\
\text { nausea }\end{array}$ & $\begin{array}{l}\text { Previous } \\
\text { stroke }\end{array}$ & $\begin{array}{c}\text { TTE } \\
\text { and TEE }\end{array}$ & RCC & $0.6 \times 0.2$ & Stroke and PFO & $\begin{array}{c}\text { Excision } \\
\text { and PFO } \\
\text { closure }\end{array}$ \\
\hline
\end{tabular}

$T T E=$ transthoracic echocardiography; $R C C=$ right coronary cusp; $L C C=$ left coronary cusp; $A V R=$ aortic valve replacement TEE = transoesophageal echocardiography; HTN = hypertension: $D M=$ diabetes mellitus; $N C C=$ non-coronary cusp; $M I=$ myocardial infarction: $A F=$ atrial fibrillation; $C K D=$ chronic kidney disease; $P A D=$ peripheral arterial disease; $C T=$ computed tomography; $C A B G=$ coronary artery bypass graft; $P F O=$ patent foramen ovale. ${ }^{*}$ In all cases, the diagnosis was confirmed via histopathological examination.

The differential diagnosis of an aortic valve myxoma includes vegetation, a thrombus, PFE and Lambl's excrescences; these conditions can be distinguished by their microscopic and immunohistochemical characteristics. ${ }^{7,10,13}$ In addition, thrombi and myxomas can be differentiated using two-dimensional echocardiography; the former typically present with a layered appearance, while an area of echolucency may be observed within the tumour in the latter. ${ }^{7}$ Moreover, vegetations of the heart valves are a sign of infective endocarditis; however, this was ruled out in the current case due to a lack of history of this condition. ${ }^{10,16}$

On imaging, the size, shape, attachment site, mobility and location of a cardiac mass can aid in the exact diagnosis, along with the patient's clinical presentation. ${ }^{17-19}$ For example, in PFE cases, the tumour appears as a small mass attached to the mitral or aortic valve, usually located downstream and attached by a small pedicle; such masses are more common and often mobile and appear irregularly-shaped with delicate frond-like surfaces. ${ }^{7,17,18}$ In contrast, Lambl's excrescences appear as filiform fronds located near valve closure lines. ${ }^{20}$ Radiologically, TEE is superior to TTE in identifying a cardiac mass and defining its exact location, attachment to the underlying tissue and relation to surrounding structures. ${ }^{21,22}$ Among previously reported cases of aortic valve myxoma, 10 were identified by TTE, of which four were further confirmed via TEE. ${ }^{5-14}$ In one case, an aortic valve abnormality was first revealed via $\mathrm{CT}^{4}$ In the current case, TEE revealed the mass to be located on the RCC of the aortic valve, thus precluding a thrombus or cardiac vegetation; however, the preoperative diagnosis was of a PFE. As with previous cases, the correct diagnosis was eventually confirmed by histopathological examination revealing a myxoid matrix with ovoid myxoma cells. ${ }^{4-14}$

Typically, the management of aortic valve myxoma cases involves the surgical excision of the tumour as well as the surrounding tissue to minimise the risk of local recurrence, as in the present case. ${ }^{4,10-12}$ During the procedure, the native aortic valve should be conserved as much as possible; however, if the tumour is too large 
and/or degeneration of the valvular structure occurs, aortic valve replacement (AVR) may be necessary. Among previously reported cases, seven underwent AVR, while resection alone was sufficient in three cases and one required resection and a coronary artery bypass graft. $^{4-14}$ Nevertheless, regardless of treatment option, aortic valve myxoma cases require careful follow-up due to the high probability of local recurrence and distal tumour growth at the site of embolisation. ${ }^{5}$

\section{Conclusion}

An aortic valve myxoma is uncommon and may present with serious complications, such as stroke. In patients with embolic phenomena, TEE should be performed, with special attention to the valvular morphology. For valvular myxomas, aggressive surgical excision is necessary to prevent structural valve degeneration and local recurrence.

\section{ACKNOWLEDGEMENTS}

The authors express their gratitude for the insightful comments of Dr Sari Alsuhaibani, Department of Radiology, KFHU, Dr Mohammed J. Alyousef, Department of Pathology \& Laboratory Medicine, KFHU, and Mr Ahmed M. Alsahlawi, Imam Abdulrahman Bin Faisal University, Dammam, Saudi Arabia.

\section{References}

1. Burke A, Virmani R. Tumors of the heart and the great vessels. In: Rosai J, Ed. Atlas of Tumor Pathology, 3rd series. Washington DC, USA: Armed Forces Institute of Pathology, 1996. P. 231

2. Vaideeswar P, Butany JW. Benign cardiac tumors of the pluripotent mesenchyme. Semin Diagn Pathol 2008; 25:20-8. https://doi.org/10.1053/j.semdp.2007.10.005.

3. Orlandi A, Ciucci A, Ferlosio A, Genta R, Spagnoli LG, Gabbiani G. Cardiac myxoma cells exhibit embryonic endocardial stem cell features. J Pathol 2006; 209:231-9. https://doi.org/10.1002/path.1959.

4. Javed A, Zalawadiya S, Kovach J, Afonso L. Aortic valve myxoma at the extreme age: A review of literature. BMJ Case Rep 2014; 2014:bcr2013202689. https://doi.org/10.1136/bcr-2013-202689.

5. Prifti E, Ademaj F, Kajo E, Baboci A. A giant myxoma originating from the aortic valve causing severe left ventricular tract obstruction: A case report and literature review. World J Surg Oncol 2015; 13:151. https://doi.org/10.1186/s12957-0150575-9.

6. Ramsheyi A, Deleuze P, D'Attelis N, Bical O, Lefort JF. Aortic valve myxoma. J Card Surg 1998; 13:491-3. https://doi.org/10.1 111/j.1540-8191.1998.tb01089.x.
7. Kim HY, Kwon SU, Jang WI, Kim HS, Kim JS, Lee HS, et al. A rare case of aortic valve myxoma: Easy to confuse with papillary fibroelastoma. Korean Circ J 2012; 42:281-3. https://doi.org/ 10.4070/kcj.2012.42.4.281.

8. Kennedy P, Parry AJ, Parums D, Pillai R. Myxoma of the aortic valve. Ann Thorac Surg 1995; 59:1221-3. https://doi. org/10.1016/0003-4975(94)00969-E.

9. Watarida S, Katsuyama K, Yasuda R, Magara T, Onoe M, Nojima T, et al. Myxoma of the aortic valve. Ann Thorac Surg 1997; 63:234-6. https://doi.org/10.1016/S0003-4975(96)00771-0.

10. Okamoto T, Doi H, Kazui T, Suzuki M, Koshima R, Yamashita T, et al. Aortic valve myxoma mimicking vegetation: Report of a case. Surg Today 2006; 36:927-9. https://doi.org/10.1007/s005 95-006-3273-y.

11. Dyk W, Konka M. Images in cardiothoracic surgery: Unusual complication of aortic valve grape-like myxoma. Ann Thorac Surg 2009; 88:1022. https://doi.org/10.1016/j.athoracsur.2008.12.051.

12. Koyalakonda SP, Mediratta NK, Ball J, Royle M. A rare case of aortic valve myxoma: An unusual cause of embolic stroke. Cardiology 2011; 118:101-3. https://doi.org/10.1159/000327081.

13. Fernández AL, Vega M, El-Diasty MM, Suárez JM. Myxoma of the aortic valve. Interact Cardiovasc Thorac Surg 2012; 15:560-2. https://doi.org/10.1093/icvts/ivs117.

14. Ji Z, Wang L, Sun J, Ye W, Yu Y, Huang H, et al. Aortic valve myxoma in a young man: A case report and review of literature. Heart Surg Forum 2017; 20:E066-8. https://doi.org/10.1532/ hsf.1772.

15. Homma S, Sacco RL. Patent foramen ovale and stroke. Circulation 2005; 112:1063-72. https://doi.org/10.1161/CIRCULA TIONAHA.104.524371.

16. Martinez G, Valchanov K. Infective endocarditis. BJA Educ 2012; 12:134-9. https://doi.org/10.1093/bjaceaccp/mks005.

17. Shelh M. Multiplane transoesophageal echocardiography detection of papillary fibroelastomas of the aortic valve causing a stroke. Eur Heart J 1997; 18:702-3. https://doi.org/10.1093/ oxfordjournals.eurheartj.a015325.

18. Watanabe T, Hosoda Y, Kikuchi N, Kawai S. Papillary fibroelastoma of the tricuspid valve in association with an atrial septal defect: Report of a case. Surg Today 1996; 26:831-3. https://doi.org/10.1007/BF00311648.

19. Rana BS, Monaghan MJ, Ring L, Shapiro LS, Nihoyannopoulos P. The pivotal role of echocardiography in cardiac sources of embolism. Eur J Echocardiogr 2011; 12:i25-31. https://doi.org/10. 1093/ejechocard/jer122.

20. Aziz F, Baciewicz FA Jr. Lambl's excrescences: Review and recommendations. Tex Heart Inst J 2007; 34:366-8.

21. Leibowitz G, Keller NM, Daniel WG, Freedberg RS, Tunick PA, Stottmeister C, et al. Transesophageal versus transthoracic echocardiography in the evaluation of right atrial tumors. Am Heart J 1995; 130:1224-7. https://doi.org/10.1016/00028703(95)90146-9.

22. Mankad R, Herrmann J. Cardiac tumors: Echo assessment. Echo Res Pract 2016; 3:R65-77. https://doi.org/10.1530/ERP16-0035. 